\title{
A Christian educational perspective on the process- oriented approach to intrinsic motivation
}

\author{
Mechaéla Scott \\ Department of Educational Psychology, Guidance and Orthopedagogics \\ Potchefstroom University for CHE \\ POTCHEFSTROOM
}

\begin{abstract}
Within the classroom context, albeit school or university, intrinsic motivation can effectively be described and changed if a process-oriented approach is emploved. The question is posed whether a process-oriented approach to motivation is acceptable 10 Christian education. To answer this question, intrinsic motivation and the process-oricnted approach to motivation are described. $A$ Cinistian view of self-knowledge and control, which are the main components of a process-oricnted approach 10 motivation, is subsequenly given and the process-oriented approach to motivation is subjected to a Chistian evaluation. The conchusions are drawn that this approach can fritfully be used in Christian edication, given that self-knowledge and control are interpreted willin the context of the concept of the student as God's representative on earth and the fact that God equipped him adequately with cognitive, affective and conative abilitics to respond to His call to discover, develop and nile the earth actively.
\end{abstract}

\section{INTRODUCTION}

God created man as his representative and ordered him to discover, develop and rule the earth. In the educational context God's call can be interpreted, inter alia, as an order to the student to learn. To enable the student to respond actively to his call, God equipped him with the necessary cognitive, affective and conative abilities. According to Berkhof (s.a.:40) and Bandura (1986:126) knowledge of, and responsible control over these abilities, form the core of intrinsic motivation.

Motivation can be described as "an internal facility for learning that sustains the desire to learn" (Corno \& Rohrkemper, 1985:53) and refers to the student's motives, intentions or goals. A student, whose learning goal is personal understanding, is intrinsically motivated, whereas a student who learns to fulfil the requirements of others and gain their approval, is extrinsically motivated (Entwistle, 1988:22). McKeachie, Pintrich, Lin and Smith (1986:85) view intrinsic motivation as the need to deal effectively with the environment in order to become more competent and pre-supposes the student's active involvement with the learning task.

Intrinsic motivation can be stimulated and enhanced through a process-oriented ap- 
proach to learning and teaching. A process-oriented approach is based on the premise that through learning, and as a result of learning, the student not only gains knowledge of his ability and competence to control his behaviour, but also becomes able to relate his performances to the value of the task and his expectancy of success (Pintrich, 1988:75). In other words, an intrinsically motivated student is a student who takes responsibility for what he can accomplish, who recognizes the true value of learning, and who forms realistic expectations of learning results.

As the process-oriented approach to motivation places much emphasis on the role of the self (i.e. self-knowledge, self-control and self-responsibility), the question is posed whether such an approach is acceptable to Christian education. To answer the question, the fundamental reflective method will be used in that motivation will be described, first from a process-oriented approach and then from a Christian perspective, after which a Christian perspective on the process-oriented approach to motivation will be given.

\section{A PROCESS-ORIENTED APPROACH TO INTRINSIC MOTIVATION}

With a process-oriented approach the student is equipped with the necessary skills and competence that enable him to become more independent of others and more dependent on himself during the learning process. The student is led to evaluate his learning performances and affective reactions in the context of not competition, social approval and high marks, but his abilities, effort, learning strategies and competence (Pintrich \& De Groot, 1990:33; Weiner, 1985:561). The knowledge the student gains about the following three components, namely the value he attaches to learning, his expectancies of success and his affective reactions, stimulates intrinsic motivation and the will to learn.

\subsection{The components of intrinsic motivation}

The value component answers the question, 'What is the task worth to me?' and deals with the student's beliefs about the importance of the task and his responsibility for performing the task. A student who views a task as important and interesting because he can improve his competence, will spend more effort on the task, even when experiencing difficulties, than a student who simply wishes to gain social recognition or high marks (Pintrich \& De Groot, 1990:33).

The expectancy component relates to the question, 'Can I perform this task?' It includes beliefs about causes of behaviour, competence, self-efficacy, control and 
responsibility (Pintrich \& De Groot, 1990:33). A student who believes that he can perform a task will invest more effort and experience, more control and responsibility, than a student who doubts himself (Pintrich, 1988:75).

The affective component answers the question, 'How do I feel about the task?' and includes the student's emotional reactions to the task (Pintrich \& De Groot, 1990:3334). Attributing performances to effort and ability evokes more pride, self-esteem and responsibility, and less anxiety than attributing performances to, for instance, good or poor teaching (Weiner, 1985:561).

By means of these self-evaluative questions the student gains knowledge of his learning goals and his competence to perform the task. The focus is on the cognitive processes, which are enabled by specific cognitive capabilities (see paragraph 2.2 ) and affective reactions, that instigate and sustain goal-oriented behaviour (Schunk, 1990:3).

\subsection{Cognitive capabilities that enable self-evaluation}

Self-evaluation is the subjective cognitive process, through which the student interprets what he is capable of doing, with the skills and abilities he believes he possesses or can gain (Bandura, 1986:391). Self-evaluation is enabled by the following capabilities, namely symbolizing, forethought, vicarious deduction, self-regulation and selfreflectivity.

- Symbolizing means to analyse personal experiences in order to extract information about the self as a learner, and to structure the information into internal models or beliefs, that serve as motivation to act. Beliefs about the causes of behaviour, about self-efficacy and about the goals of learning are based on symbolized thought, which forms the basis of the other capabilities (Bandura, 1986:106 and 349).

- Forethought is the cognitive representation of the future in the present. It enables the student to form expectancies about performances and results, or to judge performances in advance in order to plan actions to attain certain goals. Forethought induces motivation and sustained effort to act so that the cognitive representations can be realised.

- Through the vicarious capability self-knowledge is gained by comparing personal competence and possible performances to the observed behaviour of similar others (Bandura, 1986:19). The vicarious capability, as well as the self-regulatory capability, relates to both personal performances and social interactions as sources 
of self-knowledge and control.

- The self-regulatory capability enables the student to observe, judge and react to his own performances and to those of others. Behavioural patterns perceived to be effective, are identified and used. During task performance behavioural patterns are compared to the symbolized internal standard or model, and if the behavioural patterns are found to be ineffective, they are changed (Bandura, 1986:337).

- Self-reflectivity means that the same student who thinks, acts and feels, can later think about his thoughts, feelings and performances. The self-reflective capability enables the student to relate all his capabilities as a unity to his performances and to interpret the information he gains from various sources during learning (Bandura, 1986:21).

\subsection{Sources of self-knowledge and control}

Intrinsic motivation is determined by how the student interprets his learning potential in the context of the social-instructional classroom environment and learning task (Botha, 1988:16; Weiner, 1984:17). Three sources thus regulate information on selfknowledge and control, namely personal performances, social interactions and task characteristics (Botha, 1988:16; Corno \& Rohrkemper, 1985:53). These sources will each be addressed separately.

\subsubsection{Personal learning performances}

Personal performances (i.e. enactive experiences) are the most influential source of self-knowledge and control (Bandura, 1986:399). The student gains information about his motives (i.e. goals), competence (or self-efficacy) and the determinants of learning results (i.e. attributions) not only from his learning performances and results, but also from his physiological reactions. He interprets the information, relates it to preexisting self-perceptions and develops internal models, which guide and motivate behaviour (Bandura, 1986:402)

A student, for instance, forms specific perceptions of his mathematical ability through self-appraisal of prior performances in mathematical tasks occurring in subjects such as mathematics, science or geography. If he experiences difficulties in performing mathematical tasks, it can induce anxiety, which, due to lack of insight, may be interpreted as a sign of low competence, although the actual cause may be attributable to poor learning strategies. The student may thus tend to avoid accepting responsibility 
for failures, and consequently avoid such subjects even though he may actually possess high mathematical ability.

Personal performances are analysed in terms of the goal of the learning task, which can either be to improve competence (a learning orientation), or to validate competence through external evaluation (a performance orientation) (Zimmerman, 1985:118; Bandura, 1977:193). According to Dweck (1989:89) learning-oriented students experience more control over and responsibility for learning and are more intrinsically motivated than performance-oriented ones. They are willing to invest high effort into difficult tasks, have realistic self-efficacy beliefs and are less influenced by failure (Dweck, 1989:98).

As self-evaluation enables the student to determine what he can do with the skills and competence he has, it is influenced by beliefs about self-efficacy and the causes of behaviour, determining expectancies of success and emotional reactions (Pintrich, 1988:75; Bandura, 1986:391; Paris \& Winograd, 1992:23).

Successful performances raise efficacy appraisals while repeated failures lower them. The more failure is attributed to variables the student feels unable to control or alter, the more the adverse effect it has on self-efficacy. Students who are sure of their capabilities find the causes of occasional failures in variables such as poor learning strategies or low effort (Bandura, 1986:399). Those who doubt their capabilities, attribute failures to uncontrollable variables such as low ability or poor teaching methods, and suffer a decrease in self-efficacy with each new failure (Bandura, 1982:140). Students with high self-efficacy choose difficult tasks as self-efficacy sustains motivated effort even when the learning outcome is uncertain, while students with low self-efficacy avoid tasks of which the outcome is uncertain. Low self-efficacy thus influences expectancies negatively (Bandura, 1986:231).

As self-evaluation is a subjective process, self-efficacy beliefs can be based on inadequate information, misinterpretation of learning events or faulty inferences about abilities. Prior learning experiences can also create judgemental biases leading to misconceived self-efficacy (Bandura, 1986:19, 349).

Emotional reactions, which are the main instigators of motivation, are evoked by attributing causes to behavioural results (Weiner, 1985:559). If the student attributes results to causes that he can control, such as his learning strategies or amount of effort expended, he experiences pride when his results are favourable and guilt when they are unfavourable. Control and responsibility stimulate intrinsic motivation. A student who attributes results to teaching methods, the difficulty level of the task or the influence of peers, experiences little control or responsibility. Beliefs about the causes to which 
behavioural outcomes can be attributed thus evoke emotional reactions which influence expectancies of task performance and motivation (Weiner, 1988:93).

The student's goal orientation, self-efficacy and attributions interactionally influence his motivation to learn. Goal orientation determines the degree of control and responsibility the student will experience for his performances, and his level of selfefficacy and self-esteem (Zaleski, 1988:563; Corno \& Rohrkemper, 1985:58). A learning-oriented student experiences a high level of self-efficacy when he knows that he can control the behaviour needed to generate competence and skills (Czerniak \& Chiarelott, 1990:49-50). A performance-oriented student, on the other hand, experiences self-efficacy only if he judges that he already possesses the necessary competence, skills and intelligence to perform the task. A performance orientation and low selfefficacy lead to a lack of control, low expectancies of success and low levels of motivation (Bandura, 1986:129, 391).

\subsubsection{Social interactions}

Self-evaluation is influenced, among others, by social interactions with parents, teachers, and peers. The more dependable the social source, the greater the influence it has on self-knowledge and control. Positive relationships, based on reciprocal personal knowledge, form the basis of relatively stable motivational patterns incorporating learning-oriented goals, self-confidence, self-control, responsibility and selfefficacy (Entwistle, 1987:137). Social interactions as a source of information, is, however, interpreted within the pre-suppositional framework the student has already developed as a result of learning experiences.

Through the vicarious and self-regulatory capabilities the student deduces his competence from observing similar others perform a task, especially when the task is more dependent on skills, strategies and knowledge than on ability (Bandura, 1986:301). If he judges himself to be equally competent than those who succeed, he will expect to succeed as well. Should he judge himself to be less competent, he may doubt his chances of success. According to Schunk and Hanson (1989:431) the learning attributes displayed by peers influence motivation differentially. Students perceive peer-models who display mastery and verbalize positive achievement beliefs and those who experience initial difficulties, but then display coping behaviours, to be competent and themselves to be equally competent. Models who initially experience difficulties when learning, verbalize negative emotive statements and then display coping behaviours, are perceived to be less competent than the student who observes them.

Competence and skills are also interpreted in terms of feedback and expectancies of 
significant others. Considering that perceptions of a student's competence and attributions are often biased, disagreements often occur between the student's interpretation of feedback and that of teachers or parents (Juvonen, 1988:330) Whereas the student may interpret praise, help-giving and pity as a sign of low ability, he interprets blame, relative neglect and anger as a sign of high ability but low effort. How the student perceives verbal or affective feedback influences his perception of personal ability, expectations of success, affective reactions and performance (Meyer, 1982:888). Ames and Archer (1987:409) report that the mother's goal orientation influences how she views her child's learning activities, the type of feedback she gives and her expectancies. A mother with a performance orientation expects high achievement of her children - a fact which may have a detrimental effect on the student's motivation if he doubts his ability and achieves below the mother's expected level.

Positive self-evaluation and teacher praise are greatest when success is attributed to effort. Pride in own accomplishments and teacher rewards decrease, however, when success is not attributable to effort (Covington \& Omelich, 1979:688).

\subsubsection{The learning task}

The learning task serves as a source of self-knowledge and control as the student compares the difficulty level of the task to the goal he wishes to attain (i.e. his internal standard of excellence) and to the competence he would need to master the task. A moderate negative discrepancy between the task and the internal standard on the one hand, and competence on the other hand, stimulates intrinsic motivation to master the task to the level of the internal standard. A large negative discrepancy evokes feelings of hopelessness with a decrease in motivation (Kernan \& Lord, 1988:76). The student's goal orientation, level of self-efficacy and attributions for causes interactionally influence his motivation to initiate and sustain task performance.

Easy tasks need little self-confidence to be undertaken, but the student also experiences little self-esteem, self-confidence and self-efficacy if he masters them. Difficult or challenging tasks are endeavoured by students with a high level of selfconfidence, self-efficacy and self-control. Mastery of such tasks supports and raises self-confidence, self-efficacy and self-esteem (Clifford, 1988:15-16; Kroll, 1988:338). Intrinsic motivation thus has more influence on difficult tasks than on easy tasks.

A process-oriented approach to motivation thus enables the student to gain selfknowledge and control by using his cognitive capabilities to process information gained from his performances, social interactions and task characteristics. In the next 
paragraph attention is given to a Christian interpretation of the sources of selfknowledge and control leading to intrinsic motivation.

\section{A CHRISTIAN PERSPECTIVE ON THE RELATIONSHIP BETWEEN SELF- KNOWLEDGE AND CONTROL, AND INTRINSIC MOTIVATION}

According to Christian principles the relationship between God and man is the motivational basis of behaviour (Berkhof, s.a.:40), including learning behaviour, as man's behaviour ought to be directed in accordance with God's will. Man can thus only gain insight in himself as an individual and a social being, and control his behaviour, if he compares his attributes and behaviour to what God, as his origin, expects of him (Heyns, 1982:365).

\subsection{God as origin of man's self-knowledge, self-control, and motivation}

God created man analogous to Himself, and called him to be his representative on earth in what he is and does (Heyns, 1982:192). The student's behaviour (of which learning and motivation are aspects) reflects the image of God, although imperfect, as do the products of his behaviour (inter alia learning results) (Heyns, 1982:192).

Although man volitionally severed the bond between God and himself by choosing to deny his obedience to and dependence on God, Christ justified man by redeeming his sins, calling him to full obedience made possible by the Holy Spirit living in his heart (Postma, 1987:2-3). Despite the fact that man's nature has become disposed to direct his will at that which is wrong, he did not lose the ability to direct his will at that which is right. Human behaviour, including learning, is thus motivated from either a Christian or another religious radix (Van der Walt, Dekker \& Van der Walt, 1983:109).

For the Christian true self-knowledge and self-control are only gained from God's Word, which is the norm for the quality of man's existence and behaviour - thus how he ought to be and behave (Berkouwer, 1957:18). Being qualified by norms means that the student is not a passive responder, but an active agent with a will, who can control his behaviour, make choices and accept responsibility (Heyns, 1982:194). The student therefore needs to know his own vocational, volitional and control characteristics if he is to become motivated to learn. 


\subsection{Self-knowledge and self-control as a source of motivation}

Since the student is a dynamic, religious being, he has the potential to motivate himself and be motivated to learn, in full awareness of his responsibility to fulfil his vocation. God's call to discover, develop and rule the earth demands an active, obedient and responsible answer (Berkhof, s.a.:40). Such an answer requires self-reflection as the student has to know who he is and what he is capable of, before he can decide how to behave obediently and responsibly (Heyns, 1982:196). To know himself as a person and an active agent, he is to relate to God and to himself and to respond to himself as to God (Postma, 1987:2). Self-reflection in the light of the Word of God leads to selfknowledge, self-control and intrinsic motivation as it enables the student to interpret how much effort is to be expended to optimise performance and how failure is to be viewed (Heyns, 1982:364).

The student as an integrated totality with interactional functions has a body and soul, a personality, intellect and will, which make possible the functions of perception, thought, memory, conceptualisation, feelings, motivation and movement (Postma 1987:3). To gain self-knowledge of his efficacy as a learner, he must personally evaluate his learning experiences, achievements and physiological reactions in the light of his own limitations (Heyns, 1982:201-203). As God created all men equal, but not similar, such self-evaluation must lead to true knowledge and acceptance of personal abilities and limitations and prevent both over-estimation and under-estimation (Van der Walt et al., 1983:145; Heyns, 1982:367). The student must thus recognize that his abilities are human, limited, insufficient and temporary.

Although self-knowledge and self-acceptance generate self-respect, self-esteem and self-control, they do not exclude self-criticism, or value-based evaluation of insight and acknowledgement of the provisional and limited character of the human ability to know truthfully (Heyns, 1982:368). Due to his nature the student often interprets his abilities erroneously and this leads to misinterpreted self-knowledge, lack of selfacceptance, low self-esteem and poor motivation. The student therefore needs vicarious evaluation and external feedback as additional sources for the corroboration or alteration of self-knowledge.

\subsection{Social variables as a source of motivation}

The student is not passive, isolated or autonomous, but a socially responsible and active human being who can motivate himself and be motivated also by observing and evaluating the behaviours of others (Berkhof, s.a.:28). He stands as an integrated, but differentiated person in relationship to his fellowmen in reciprocal discovery and 
recognition of each other. The status and position of each in the relationship not only determine the nature of interpersonal relationships, but also the self-knowledge the student deduces from such relationships which are characterized by a balance between authority and independence (Duvenage, 1983:113). Self-knowledge and self-control derived from a relationship with the teacher therefore differ from what is derived from peer-relationships and have a differential effect on his motivation. The teacher's position of authority lends more weight to his evaluation of the student's abilities and therefore influences the student's beliefs about self-efficacy more than the evaluation of peers or parents, who are often not recognized as authorities on the subject of learning.

Interpersonal relationships are, however, based on the personal relationship with God If this relationship is severed, the student's relationship with himself, others and the learning task is also disturbed (Duvenage, 1983:110). His self-knowledge, selfacceptance, self-esteem, and self-respect then concur with an evaluation of his learning goals and efficacy as a learner which is based on norms set by others, instead of by God's Word (Postma, 1987:3; Van der Walt et al., 1983:104). Social sources of selfknowledge and control affecting intrinsic motivation must therefore also be evaluated within the religious perspective if they are to be interpreted truthfully.

\subsection{Learning behaviour as a source of self-knowledge and motivation}

The student's God-given potentialities find expression in his learning behaviour. In the motivational context this implies that the student who knows his learning potential will be motivated to use it when learning.

The student learns in response to God's call to discover, develop, conserve and create from nature what God has placed in nature (Berkhof, s.a.:26). There is thus an interdependence between him and his learning tasks, or a means-goal relationship, as performing the tasks motivates him to discover and develop his competence. Such discovery and development can be viewed as the fruits of labour which can be interpreted in three ways (Van der Walt et al., 1983:148). In the first place, fruits of labour symbolize creative talent. Through learning the student improves his ability to transform something into something different, such as using his language ability to write an essay. Fruits of labour secondly refer to the control and development of one's inherent nature. As such, teaching and educating also bear fruits of labour, as the student learns who he is and how he can control himself, not only by personally evaluating his learning behaviour, but also by being evaluated by others. The fruits of labour are thirdly manifested in behavioural results. To the student this refers to the results of his learning; to the educator it refers to the results his teaching has on 
developing the student's learning potential while, to the educationist, it refers, inter alia, to the theories or approaches he constructs to explain educational phenomena. In motivational context, the student, the educator and the educationist must constantly evaluate the fruits of their labour in the light of God's Word to determine whether they are conforming to the religious radix determining self-knowledge (Duvenage, 1983:118-119).

\section{A CHRISTIAN EVALUATION OF THE PROCESS-ORIENTED APPROACH TO MOTIVATION}

The educational goal of the process-oriented approach to motivation will be analysed and evaluated, followed by an evaluation of the religious radix of the approach and the sources from which self-knowledge, self-control and motivation evolve.

\subsection{The educational goal of the process-oriented motivational approach}

As modern society is characterised by increasing individualisation and technological advances, the student is constantly confronted by choices which he has to evaluate in order to make responsible decisions on which he can act (Levering \& Smeyers, 1989:133-135). In the learning context he can motivate himself, and be motivated, to do so only if he knows himself as an integrated totality whose cognition, affect, conation and body function interactionally (Zaleski, 1988:563; Bandura, 1986:129,391). The aim or goal of the process-oriented motivational approach is to develop these functions so that the student can gain the self-knowledge and control necessary to regulate and motivate his learning behaviour in a responsible manner (Schunk, 1990:3). According to Cuypers (1989:189) and Snik (1989:121) self-knowledge, self-control and responsibility are, however, not goals motivating behaviour, but norms for planning and executing behaviour. The goal motivating behaviour, also learning behaviour, is to glorify God and to answer His command in a responsible manner. The true goal of learning for which the student is to become motivated, is thus not addressed by this approach.

Self-knowledge, self-control and responsibility also mean different things to different people as the connotations attached to these concepts are determined by the religious principles of the interpreter. Therefore the religious radix on which the processoriented approach to motivation is based, will be evaluated from a Christian perspective. 


\subsection{The religious radix of the process-oriented motivational approach}

The Christian view of man underlying motivation is based on the principle of responsibility and self-control gained through self-knowledge. Learning and gaining selfknowledge are therefore not voluntary acts, but God's commands which have to be answered in a responsible manner. Cuypers (1989:171) argues that as God endowed the student with the capability to learn and the will to choose and decide, he is responsible in the sight of God for his learning behaviour, performances and achievements and therefore needs to fulfil these actions in a motivated manner (Sturm, 1989:80). Although sin tarnished man's sense of responsibility so that he often directs his will at pleasing himself and others, instead of God, it does not exonerate him from bearing the responsibility for his own behaviour (Berkhof, s.a.:68).

Although the process-oriented approach to motivation relates the student's evaluation of his abilities, competence and behaviour to personal responsibility, the religious source of the concepts is not recognized, and man is consequently elevated to become the norm of his own behaviour (Berkhof, s.a.:91). This forms the main limitation of this approach, as motivated behaviour needs to be placed in the context of Scripture and the nature of man, not only as an individual, but also as a social being. Motivation is therefore a social-psychological process based on religious norms (Cuypers, 1989:193).

\subsection{Sources from which self-knowledge, self-control and responsibility are deduced}

The anthropological perspective of the process-oriented approach to motivation consists of three aspects.

- Firstly, according to this approach, the student is not driven by inner forces, nor controlled by environmental circumstances, but is wilfully able to direct his own learning behaviour (Pintrich, 1988:75; Bandura, 1986:21). The approach thus recognizes the active character of the student, and endeavours to create in him a questioning disposition in order to enable him to base his behaviour on wellthought out choices and values (Cuypers, 1989:188). This also implies that the student is able to carry the full responsibility for his motivated behaviour.

- Secondly, the approach recognizes that the student is an integrated totality in whom both the cognitive and affective aspects of human nature form part of motivation, as cognitive evaluation of affective reactions leads to logical feelings (such as love or self-esteem) about the self. Much attention is given to the emotional state of the learner as emotions (differentiated by cognition) such as guilt, shame and self-efficacy are recognized as the main instigators of action. Perseverance, 
self-control, self-efficacy, responsibility, self-helplessness and self-acceptance are central themes, as is positive self-esteem, which stimulates motivation and prevents self-helplessness (Weiner, 1985, 559; 1988:93)

- Thirdly, the fallible character of human nature is recognized. As human insight is not perfect, misinterpretation of personal abilities and behaviour and of the task difficulty and other environmental factors can occur (Kernan \& Lord, 1988:76; Clifford, 1988:15-16; Kroll, 1988:338). The same concepts which are used to describe rational behaviour, namely values, goal orientation, expectancies, selfefficacy, attributions and emotions, are also used to describe what appears to be irrational behaviour. The value that the student attaches to learning is based on internalised norms. Such norms can, however, be based on misinterpretation of personal abilities leading to unattainable goals and poor motivation. Students are not viewed as super-humans with unlimited insight, but fallible beings apt to perceive things as they wish them to be. They can therefore over-estimate or under-estimate themselves and suffer loss of self-esteem and self-efficacy.

These three aspects characterizing human nature suitably explain motivation, also from a Christian perspective. What has once again been omitted, however, is the relationship between the student's ability, or inability, to instigate and interpret his own actions and the religious source of such interpretation, namely Scripture.

As concerns the social aspects of motivation, the process-oriented approach to motivation not only recognizes the student as an individual, but also as a social being who can be motivated through vicarious experiences, feedback and modelling (Bandura, 1986:111, 301; Entwistle, 1987:137). Beliefs stimulating the motivation to act are also inferred from the reactions of significant others, such as parents, peers and teachers. The influence of others, however, is determined by the dependability of such sources and by how the student perceives them. The student is not controlled by external forces, but interprets them and acts according to his own perception of these forces. The process-oriented approach places achievement motivation in the perspective of the classroom situation and explains the influence of competition on especially goal orientation. The student is thus not viewed as a self-sufficient individual, totally independent, but is perceived to be an individual-social human being who can also be motivated by others. Self-esteem, especially, is dependent on an acknowledgement of one's personal abilities by others, as the student mirrors himself in the eyes of others.

What is problematic, however, is that man himself is taken to be the norm for his own behaviour, whereas, from a Christian perspective, God's Word is the criterion for behaviour, and not societal norms (Snik, 1989:122). The solution for the conflict between man and society, autonomy and authority, individuality and adaptation is to be 
found in religious norms (Sturm, 1989:82).

\subsection{Conclusions}

Self-knowledge, self-control, self-efficacy and self-esteem are acceptable motivational concepts as a Christian perspective of these concepts is based on the Word of God. The process-oriented approach to motivation succeeds in relating these concepts to the interaction of the cognitive, affective and conative components of the student. Behaviour is thus motivated in accordance with what the student believes about his own capabilities, how he feels about himself and at which goals he directs his will.

The student is seen to be an integrated totality and as a part of a community. He is not self-sufficient, but has to rely also on others to come to full recognition of who he is and what he can do. The cognitive component is not absolutised, but is seen as the basis of the affective and conative components, deepening affect to logical emotion and thus influencing will-direction. Individual differences between students are explained according to their differential abilities and limitations and the fallible nature of human insight is recognized. The student is enabled to maximise his learning potential by means of a realistic interpretation of what he can accomplish with whatever potential he has.

The process-oriented approach to motivation thus enables the student to answer God's call with an active motivated response. What the student is and can do must, however, be interpreted in the context of both his vocation and his origin.

\section{BIBLIOGRAPHY}

AMES, A. \& ARCHER, J. 1987. Mothers' Beliefs about the Role of Ability and Effort in School Lcarning. Joumal of Educational Psychology, 79(4):409-414.

BANDURA, A. 1977. Self-efficacy: Toward a Unifying Theory of Behavioral Change. Psychological Review, 84(2): 191-215

BANDURA, A. 1982. Self-efficacy Mechanism in Human Agency. American Psychologist, 37(2):122-147.

BANDURA, A. 1986. Social Foundations of Thought and Action. A Social Cognitive Theory. Englewood Cliffs, New Jersey : Prentice-Hall.

BERKHOF, H. s.a. Teologiese boekreeks, nommer 10: Wat is die mens? Genadendal : Genadendalse drukkery.

BERKOUWER, G. C. 1957. De mens het beeld Gods. Kampen : J. H. Kok.

BOTHA, T. R. 1988. Motivering. Enkele dissonante dimensies. Pretoria : HAUM.

CLIFFORD, M. M. 1988. Failure and Tolerance and Academic Risk-taking in Ten- to Twelve-year-old Students. British Joumal of Educational Psychology, 58(1):15-27. 
CORNO, L. \& ROHRKEMPER, M. 1985. The Intrinsic Motivation to Learn in Classrooms (In Ames, C. \& Ames, R., eds. Research on Motivation in Education. Vol. 2: The Classroom Milicu. Orlando, Florida : Academic Press. p. 53-90.)

COVINGTON, M. V. \& OMELICH, C. L. 1979. It's Best to be Able and Virtuous too: Student and Teacher Evaluative Responses to Successful Effort. Journal of Educational Psychology, 71(5):688-700.

CUYPERS, S. E. 1989. Zelf-opvoeding en zorg voor zichzelf. Pedogogisch Tijdschrift, 14(2):188-196.

CZERNIAK, C. \& CHIARELOTT, L. 1990. Teacher Education for Effective Science Instruction - A Social Cognitive Perspective. Joumal of Teacher Education, 41(1):49-58.

DWECK, C. S. 1989. Motivation. (In Glaser, A. \& Glaser, R., eds. Foundations for a Psychology of Education. Hillsdale, New Jerscy: Lawrence Erlbaum. p. 87-136.)

DUVENAGE, B. 1983. Roeping en wetenskap. Handleiding vir Wetenskapslecr. Potchefstroom : Bentoti. p. 93-137.

ENTWISTLE, N. 1987. Motivation to Learn: Conceptualisations and Practicalities. British Joumal of Educational Studies, 35(2):129-148.

ENTWISTLE, N. 1988. Motivational Factors in Students' Approaches to Learning. (In Schmeck, R. R., eds. Learning Strategies and Learning Styles. New York : Plenum Press. p. 21-51.)

HEYNS, J. A. 1982. Teologiese etiek. Pretoria : N.G.Kerkbockhandel. p. 59-66, 192-210, 363-388.

JUVONEN, J. 1988. Outcome and Attributional Disagreements between Students and Their Teachers. Joumal of Educational Psychology, 80(3):330-336.

KERNAN, M. C. \& LORD, R. G. 1988. Effects of Participative vs. Assigned Goals and Feedback in a Multitrial Task. Motivation and Emotion, 12(1):75-86.

KROLL, M. D. 1988. Motivational Orientations, Views about the Purpose of Education, and Intellectual Styles. Psychology in the Schools, 25:338-343.

LEVERING, B. \& SMEYERS, P. 1989. Persoonlijke verantwoordelijkheid als pedagogische basiswaarde aan het einde van de twintigste ceuw. Pedagogische Tijdschrift, 14(2):132-140.

McKEACHIE, W. J., PINTRICH, P. R., LIN, Y. \& SMITH, D. A. F. 1986. Teaching and Learning in the College Classroom: A Review of the Research Literature. Ann Arbor, Michigan : University of Michigan, National Center for Research to Improve Postsecondary Teaching and Learning (NCRIPTAL).

MEYER, W. 1982. Direct Communications about Perceived Ability Estimates. Joumal of Educational Psychology, 74(6):888-897.

PARIS, S. G. \& WINOGRAD, P. 1992. How Metacognition can Promote Academic Lcarning and Instruction. (In Jones, B. F. \& Idol, L., eds. Dimensions of Thinking and Cognitive Instruction, Vol. 1. Hillsdale, New Jersey : Lawrence Erlbaum.)

PINTRICH, P. R. 1988. A Process-oriented View of Student Motivation and Cognition. (In Stark, J. S. \& Mets, L., eds. Improving Teaching and Learning (hrough Research. New Directions for Instructional Research, no. 57. San Francisco : Jossey-Bass. p. 65-79.)

PINTRICH, P. R. \& DE GROOT, E. V. 1990. Motivational and Self-regulated Learning Components of Classroom Academic Performance. Joumal of Educational Psychology, 82(1):33-40.

POSTMA, W. 1987. Kind, ouer en opvocding. Potchefstroom : Dept. Sentrale Publikasies, PU vir CHO. p. 1-7.

SCHUNK,D. H. 1990. Introduction to the Special Section on Motivation and Efficacy. Journal of Educational Psychology, 82(1):3-6.

SCHUNK, D. H. \& HANSON, A. R. 1989. Influence of Peer-model Attributes on Children's Beliefs and Learning. Joumal of Educational Psychology, 81(3):431-434.

SNIK, G. L. M. 1989. De relatie tussen initiatie in tradities en de ontwikkeling van persoonlijke verantwoordclijkhcid. Pedagogisch Tijdschnft, 14(2):119-131.

STURM, J. C. 1989. Opkomst cn ondergang van de opvoeding? Pedagogisch Tijdschrift, 14(2):76-88. 
VAN DER WALT, J. L., DEKKER, E. I. \& VAN DER WALT, I. D. 1983. Die opvoedingsgebeure: 'n Skrifmatige perspektief. Potchefstroom : Instituut vir Reformatoriese Studies (Wetenskaplike bydracs van die PU vir CHO. Reeks F3 Versamelwerke, nr. 18. p. 92-188.)

WEINER, B. 1984. Principles for a Theory of Student Motivation and their Application within an Attributional Framework. (In Ames, R. E. \& Ames C., eds. Research on Motivation in Education: Vol, 1. Student Motiyation. New York : Academic Press.)

WEINER, B. 1985. An Attributional Theory of Achievement Motivation and Emotion. Psychological Review, 92(4):548-573.

WEINER, B. 1988. Attribution Theory and Attributional Therapy: Some Theoretical Observations and Suggestions. British Joumal of Clinical Psychology, 27:93-104.

ZALESKI, Z. 1988. Attributions and Emotions Related to Future Goal Attainment. Journal of Educational Psychology, 80(4):563-568.

ZIMMERMAN, B. J. 1985. The Development of "Intrinsic" Motivation: A Social Lcarning Analysis. Annals of Child Development, 2:117-160. 